\title{
Appraising the Physico-chemical Characteristics and Heavy Metals in Pond Water at Quarry Site in Ngwogwo, Ebonyi State, Nigeria
}

\author{
Ogbonna P. C. ${ }^{1,}$, Ukpai N. P. ${ }^{2}$, Obasi, K. O. ${ }^{3}$ and Umezuruike S. O. ${ }^{4}$ \\ ${ }^{1,2,3,4}$ Department of Environmental Management and Toxicology, Michael Okpara University of Agriculture, \\ Umudike, Abia State, Nigeria \\ Corresponding Author: *ogbonna_princewill@yahoo.com
}

https://doi.org/10.36263/nijest.2020.02.0203

\begin{abstract}
Quarrying as a land use is a potential source of water pollution but lack of access to safe drinking water has impelled people to make use of pond water from quarry sites. This study investigated the physico-chemical parameters and heavy metals of water samples collected at China quarry site in Ngwogwo Ivo Local Government of Ebonyi State, Nigeria. The concentrations of Cd $(0.01 \pm 0.00$ to $0.02 \pm 0.00 \mathrm{mg} / \mathrm{l}), \mathrm{Pb}(6.70 \pm 0.78$ to $7.87 \pm 1.08 \mathrm{mg} / \mathrm{l})$, $\mathrm{Ni}(1.03 \pm 0.04$ to $1.37 \pm 0.04 \mathrm{mg} / \mathrm{l})$, As (1.99 \pm 0.02 to $2.35 \pm 0.09 \mathrm{mg} / \mathrm{l}), \mathrm{Fe}(3.66 \pm 0.44$ to $4.18 \pm 0.04 \mathrm{mg} / \mathrm{l})$ and $\mathrm{Zn}(2.47 \pm 0.06$ to $3.17 \pm 1.13$ $m g / l)$ were higher than the permissible limit of drinking water by World Health Organization, WHO and Standard Organization of Nigeria, SON. Also, the values of biochemical oxygen demand, $B O D(37.57 \pm 1.44$ to $53.13 \pm 0.86 \mathrm{mg} / \mathrm{l})$, chemical oxygen demand, $C O D(59.55 \pm 0.51$ to $61.28 \pm 0.64$ $\mathrm{mg} / \mathrm{l})$, dissolved oxygen, $\mathrm{DO}(5.14 \pm 1.51$ to $5.75 \pm 1.09 \mathrm{mg} / \mathrm{l}), \mathrm{Mn}(3.64 \pm 0.91$ to $5.10 \pm 1.27 \%)$ and $\mathrm{Ca}(91.88 \pm 0.18$ to $102.83 \pm 0.59 \%)$ were higher than the permissible limit recommended by WHO. Consequently, it is recommended that quarry workers and inhabitants of Ngwogwo should be discouraged from making use of the pond water since it is not fit and will expose them to serious health challenges. In addition, Ebonyi State Government should demand Environmental Impact Assessment report from miners before issuing operating license to them.
\end{abstract}

Keywords: Quarry, Pond Water, Heavy Metal, Macro-nutrient, Physical Properties

\subsection{Introduction}

Safe drinking water is very essential for sustenance of good health and livelihood of people living in both urban and rural areas. It carries nutrients to all cells in our body, flushes out toxins and waste as well as regulates body temperature. Thus, the provision of safe drinking water is a basic human need over the world. In Nigeria, most rural communities do not have access to safe drinking water (Egboh and Emeshili, 2007) and where some water sources are available; its quality remains questionable with potential health risks (Okovido et al., 2018). Thus, many rural dwellers suffer the burden of walking long distances in search of water for daily domestic use (Ogbonna et al., 2020a). It is estimated that about sixty (60) million Nigerians lack access to portable drinking water (Majuru et al., 2011).

Quarrying is an activity embarked by man to extract non-metal and nonfuel minerals from rock and mining of precious metals and other types of solid minerals forms an important part of many countries' economy (Okere et al., 2001; Ogbonna et al., 2011; Ogbonna et al., 2020b). Notwithstanding this, abandoned quarry sites are often filled with groundwater and rainwater drainage, leaving behind an artificial lake basin (Ruuskanen et al., 2013). As a result of lack of access to clean water, communities inhabiting quarrying sites sometimes source water from quarry ponds for washing of clothes, bathing among others. For instance, the use of abandoned mining ponds in Bestari Jaya Selangor, Malaysia has been initiated by the State Water Authority as an alternative water resource to cater for the increasing water demand (Madzin et al., 2015). Globally, records showed that about 780 million people do not have access to clean and safe water and around 2.5 billion people do 
not have proper sanitation (Rahmanian et al., 2015). Consequently, around 6 to 8 million people die each year due to water related diseases and disasters (UN-Water, 2013). Therefore, water quality control is a top-priority policy agenda in many parts of the world (WHO, 2011). Water quality and suitability for use are determined by its taste, odor, colour, and concentration of organic and inorganic matters (Dissmeyer, 2000).

Previous studies showed that mining is a major source of potentially toxic element as heavy metal in the environment (Kusin et al., 2012, 2014; Kusin and Aris, 2014; Benvenuti et al., 1997; Asklund and Eldvall, 2005; Wang and Mulligan, 2005; Navorro et al., 2007; Schwab et al., 2007; Ogbonna et al., 2012; Ogbonna et al., 2018a; Ogbonna et al., 2020b). The accumulation of dissolved heavy metals in water is hazardous to water bodies and human health when their values are higher than the corresponding threshold (Pape et al., 2012; Varol et al., 2013; Bu et al., 2015; Ogbonna et al., 2020a). Potentially toxic elements have proven to be a major threat and there are several health risks associated with them (Mathew et al., 2014) which include dermal, respiratory, cardiovascular, gastrointestinal, haematological, hepatic, renal, neurological, developmental, reproductive, immunological, genotoxic, mutagenetic, and carcinogenic effects (Lin et al., 2013).

Drilling of boreholes as alternative source of safe drinking water is very difficult and unachievable task in some part of Ebonyi State due to salt deposit and tremendous formation of bedrocks down the soil profile/aquifers. For instance, inhabitants of Ivo local government area depend mostly on rainwater and very few streams/rivers which are far from most clans and communities. During the dry season, families rely heavily on hand-dug wells and pond waters for domestic activities such as washing of clothes, bathing, cleaning of house floors as well as irrigation of vegetables among others. The pond water might be contaminated by heavy metals released via rock chemical weathering, atmospheric deposition, mine wastewater discharge, surface and subsurface runoff. The use of such pond water may be a route of entry of contaminants (e.g. heavy metals) into human body, hence there is need to investigate the quality and safety of pond water at China quarry site in Ngwogwo, Ebonyi State. Several studies have been carried out on water quality of pond waters at mining sites which include a quantitative study of the winter plankton of Urschel's quarry (Cowell, 1960), community structure and coexistence of an artificial crater lake (Bogaert and Dumont, 1989), controls on pit lake water quality at sixteen open-pit mines in Nevada (Shevenell et al., 1999), limnological study on a lake formed in a limestone quarry in Kraków, Poland (Galas, 2003), limnological study of a lake formed in limestone quarry in Kraków, Poland (Ślusarczyk, 2003). Other studies include physicochemical properties and heavy metal content of selected water sources in Ishiagu, Ebonyi State- Nigeria (Akubugwo et al., 2012), the environmental properties of water-filled Ojamo limestone quarry, southern Finland (Ruuskanen et al., 2013), diversity of freshwater invertebrates in Wazo Hill quarry ponds in Tegeta area, Tanzania (Mahulu et al., 2015), comparing heavy metal mobility in active and abandoned mining sites at Bestari Jaya in Selangor, Malaysia (Madzin et al., 2015). Furthermore, dissolved radon and uranium in groundwater in a potential coal seam gas development region in Richmond River Catchment, Australia (Atkins et al., 2016) and metal pollution assessment of the abandoned mine ponds and ground water of parts of the Jos Plateau, North Central Nigeria (Zang and Edafetano, 2017). Most of these studies documented species assemblages and limnological properties of pond waters while others dwelt only on concentration of heavy metals in pond water. Research on water quality assessment in Ebonyi State, Nigeria are: physicochemical water quality indicators of groundwater (i.e. boreholes) samples from five communities (Ukiwe et al., 2012), analysis of spring water quality in Ebonyi South Zone and its health impact (Afiukwa and Eboatu, 2013), trace metal toxicity in our environment: case studies of influx of metals in soils, crops, waters and air (Itumoh et al., 2013), quality assessment of selected groundwater samples in Amike-Aba Abakaliki Local Government (Ngele et al., 2014), physiological parameters and nutrients variations of streams and rivers in Abakaliki Local Government (Omaka et al., 2014), assessing the suitability of surface water for domestic purposes in Uburu in Ohazara Local Government (Babatunde and Umahi, 2014), comparative analysis and treatment of well water (Iganga et al., 2015). In furtherance of this, assessment of heavy metal contamination of water sources from Enyigba $\mathrm{Pb}-\mathrm{Zn}$ district in Abakiliki Local Government (Nnabo, 2015), assessment of contamination of underground water sources in Enyigba $\mathrm{Pb}-\mathrm{Zn}$ district in Abakiliki Local Government using metal enrichment and pollution indices (Nnabo, 2015), evaluation of physicochemical parameters of selected rivers (Ani et al., 2016), comparative assessment of heavy metals in drinking water sources from Enyigba community in Abakaliki (Aloke et al., 2019) and quality audit of drinking water sources in Ikwo rural setting of 
Ikwo Local Government (Titilawo et al., 2020) of Ebonyi State, Nigeria. The work by Akubugwo et al. (2012) focused on water quality assessment of selected hand dug wells in Ishiagu, Ebonyi State. There is no information available in the scientific literature on physico-chemical characteristics and heavy metals of pond waters at China quarry site in Ngwogwo, Ebonyi State, Nigeria. This study, therefore, appraised the physico-chemical characteristics and heavy metals of pond water at China quarry site and the result obtained were compared to permissible limits set by World Health Organization, WHO (2003, 2007, 2011), Federal Ministry of Environment (FMEnvi, 2011), Standard Organization of Nigeria (SON, 2007) and Federal Environmental Protection Agency (FEPA, 1991) to ascertain its status and suitability for human use.

\subsection{Methodology}

\subsection{Study area}

China quarry site is located in Ngwogwo in Ishiagu, Ebonyi State, Nigeria. It is located on the plains of the South-eastern savannah belt and lies within Latitudes $5^{\circ} 51^{\prime}$ and $5^{\circ} 59^{\prime} \mathrm{N}$ and Longitudes $7^{\circ} 24^{\prime}$ and $7^{\circ} 40^{\prime} \mathrm{E}$. The area falls within the tropical rainforest belt of Southeastern Nigeria (Keay, 1959). It has an average temperature of $27^{\circ} \mathrm{C}$ and annual precipitation of about $1,925 \mathrm{~mm}$ (Ofomata, 2002). It experiences two seasons viz, the wet and dry seasons. The dry season start from December and end in March while the wet season commence from April and end in November (Ogbonna et al., 2020b). The highest elevation is about $110 \mathrm{~m}$ above sea level and formed by erosion-resistant igneous intrusive while the lower areas are underlain by soft rocks (Edeani, 2015). The composition of the igneous rocks at Ishiagu range from intermediate to basic (Ofoegbu, 1985). The major industrial activities located in the area include $\mathrm{Pb} / \mathrm{Zn}$ mines and quarry sites. The people of the area depend primarily on surface water bodies such as streams, wetlands and pit lakes. The pit lakes were formed by the activities of quarrying and mining companies. The settlers are predominantly farmers that produce mainly cassava, yam, maize, rice among others.

\subsection{Water sample collection and analysis}

Reconnaissance survey was carried out prior to sample collection to identify among other things the positions of the pond waters, the terrain, wind direction, and the major activities going on in the China quarry site. Three (3) large pond water in the South east (SE), South west (SW), and South central (SC) directions of the China quarry site were selected for collection of water samples. The rationale for the selection is for spread and even distribution of pond water sampling at the site so as to remove bias and reduce or limit the level of error. The ponds are designated P1 for South central, P2 for South east, and P3 for South west sampling stations while the control sample was collected from a small stream located about $4 \mathrm{~km}$ from the quarry where there was no visible source of contamination. Dark brown glass bottles (1 litre) were used to collect water samples for $\mathrm{pH}$ and dissolved oxygen, DO analyses. Polyethylene bottles were used for collection and storage of water samples for other chemical analyses (Chia et al., 2011). Each sampling bottles of one (1) liter by volume were preconditioned with 5\% nitric acid and later rinsed thoroughly with distilled de-ionized water. At each sampling station, the sampling bottles were rinsed with sampled water three times before sampling was done. The pre-cleaned sampling bottles were filled to the brim at a depth of $1 \mathrm{~m}$ below the wastewater in four (4) cardinal points (N, S, E and W) and central (C) of each pond water (e.g. 5 bottles from each sampling station i.e. pond water). The five representative water samples from each sampling station and control were acidified with $10 \% \mathrm{HNO}_{3}$ analytical grade, covered air-tight, labeled well, placed in an ice-chest container and transferred to the laboratory for pre-treatment and analysis. The portion of the water sample for metal analysis were treated with $1 \mathrm{ml}$ of Hydrochloric acid $(\mathrm{HCl})$ in $500 \mathrm{ml}$ sample to arrest microbial activities while those for non-metal analysis were freshly refrigerated in a cooler packed with, ice blocks to avoid microbial action affecting their concentration. While in the laboratory; they were stored in the refrigerator at about $4^{\circ} \mathrm{C}$ prior to the analysis (APHA, 1998). Sixty (60) water samples were collected every nine (9) days in February 2019 from the three (3) sampling stations and control site. Thus, a total of 180 water samples were collected in all. 


\subsection{Determination of the physic-chemical parameters}

Water temperature $\left({ }^{\circ} \mathrm{C}\right)$ readings were taken in situ using a mercury thermometer. Total dissolved solids (TDS) and $\mathrm{pH}$ were measured using a portable Hanna $\mathrm{pH} / \mathrm{TDS} / \mathrm{temperature}$ meter (model no H1991300). The modified Winkler azide method (Lind 1979, APHA 1998) was used to determine dissolved oxygen (DO) and biochemical oxygen demand (BOD). DO and BOD5 were titrimetrically determined after fixation with winkler solutions at day 1 (for DO) and day 5 (for BOD5) respectively. The calculated difference between DO (Day 1) and (Day 5) was recorded as BOD5 concentration in $\mathrm{mg} / \mathrm{l}$ units. Total suspended solids (TSS), total alkalinity (TA) and chemical oxygen demand (COD) concentration were titrimetrically determined using the procedure of APHA (1998).

\subsection{Determination of heavy metals and macronutrients}

The five representative water samples from each sampling station (e.g. N, S, E, W and C from P1) were mixed to form a homogenous sample. A $250 \mathrm{ml}$ from each of the acidified water was measured and transferred into separate clean conical flask and $5 \mathrm{ml}$ of nitric acid were added to each of the conical flasks. The mixture was placed on a Bunsen burner to heat at $100^{\circ} \mathrm{C}$ with addition of few drops of hydrogen peroxide until there were no brown visible fumes coming out, and volume reduced to about $5 \mathrm{~cm}^{3}$. The mixture were filtered separately with Whatman $0.45 \mu \mathrm{m}$ filter paper in a $25 \mathrm{ml}$ volumetric flask and topped to labeled mark with water. The analyses for heavy metals and macronutrients in the samples were carried out in triplicates using the Atomic Absorption Spectrophotometer (Unicam Solar 969 with acetylene air flame). For the background correction, six (6) blanks were digested as pre-test samples and each analyzed for $\mathrm{Pb}, \mathrm{Ni}, \mathrm{As}, \mathrm{Zn}, \mathrm{Cd}, \mathrm{Fe}, \mathrm{Na}, \mathrm{K}, \mathrm{Mg}$, $\mathrm{Mn}, \mathrm{Co}$ and $\mathrm{Ca}$ using AAS.

\subsection{Results and Discussion}

\subsection{Potentially toxic elements $(\mathrm{mg} / \mathrm{kg})$ in pond water}

Table 1 summarized the concentration of heavy metals in all the water samples collected from the Ponds at the China quarry site and the control site. The result indicates that the highest and lowest concentrations of heavy metals in water were obtained at the quarry and control sites, respectively. The high concentration of heavy metal in water samples from the quarry area is attributed to dust and water drainage from the quarry that leached and deposited pollutants such as heavy metal into the pond water. Terrestrial and aquatic bodies adjoined to source of pollution are recipients of contaminants such as heavy metals (Ogbonna et al., 2019; Ogbonna et al., 2020a). From the results, the highest concentration of $\mathrm{Cd}(0.02 \pm 0.00 \mathrm{mg} / \mathrm{kg})$, As $(2.35 \pm 0.09 \mathrm{mg} / \mathrm{kg})$ and $\mathrm{Ni}(1.37 \pm 0.04 \mathrm{mg} / \mathrm{kg})$ were obtained in water samples collected from Pond 1 , and the values are significantly $(\mathrm{P}<0.05)$ higher than their corresponding values in Pond $2(0.01 \pm 0.00,2.08 \pm 0.04$ and $1.05 \pm 0.03 \mathrm{mg} / \mathrm{kg})$, Pond $3(0.01 \pm 0.00,1.99 \pm 0.02$ and $1.03 \pm 0.04 \mathrm{mg} / \mathrm{kg})$, and control $(0.001 \pm 0.00,0.04 \pm 0.13$ and $0.05 \pm 0.04$ $\mathrm{mg} / \mathrm{kg}$ ). The Pond 1 might be the highest recipient of contaminants (heavy metals) released from quarry activities such as blasting, crushing, and transportation and wind deposition of dust at China quarry area. Quarry activities such as blasting, transportation and disposal of waste rocks cause dustair pollution (Nwachukwu et al., 2018) that settle on soil, plants and water bodies resulting to heavy metal pollution (Ogbonna et al., 2011). From personal observation, quarry workers cleaned their bodies mostly in Pond 1 after work on daily basis especially during the dry season. This might have enhanced the level of heavy metals in Pond 1 since heavy metals are part of dust particles washed into it (Pond 1). The concentration of Cd increased from $0.01 \pm 0.00$ (Pond 3) to $0.02 \pm 0.00 \mathrm{mg} / \mathrm{kg}$ (Pond 1) and the values are lower than $0.03 \pm 0.01$ to $0.53 \pm 0.01 \mathrm{mg} / \mathrm{kg}$ (Akubugwo et al., 2012) and 0.01 to 0.43 $\mathrm{mg} / \mathrm{l}$ (Anyanwu and Onyele, 2018) but higher than $0.00015 \pm 0.00 \mathrm{mg} / \mathrm{l}$ (Ogbonna et al., 2018b). The concentration of $\mathrm{Cd}$ in Pond 1 is 2, 2 and 20 times higher than its corresponding values in Pond 2, Pond 3 and control, respectively. The highest concentration of $\mathrm{Cd}(0.02 \pm 0.00 \mathrm{mg} / \mathrm{kg})$ in pond water samples from China quarry site is higher than the permissible limits of $0.003 \mathrm{mg} / \mathrm{kg}$ (Cd) recommended by the World Health Organization (WHO, 2003) as well as $0.01 \mathrm{mg} / \mathrm{kg}(\mathrm{Cd})$ set by Standard Organization of Nigeria (SON, 2007) (Table 2). Consequently, the concentration of Cd in water samples from the ponds can pose a serious health challenges to quarry workers and animals that inhabits the quarry area since the animals may likely drink from the ponds when thirsty. Cadmium has no bio-importance and it is toxic to all life, including fish, birds, plants, mammals (including man), and microorganisms (Eisler, 1985; Nolan, 2003; Young, 2005; Nordberg et al., 2007, ATSDR 2008; Ogbonna et al., 2018c) and it cause adverse changes in the arteries of human kidney and replaces 
zinc biochemically and cause high blood pressures and kidney damage (Feng et al., 2011) and interferes with enzymes and cause a painful disease called Itai-itai (Sperotto et al., 2014). It also affects human brain and bones (Jarup et al., 2000).

The concentration of $\mathrm{Ni}$ increased from $1.03 \pm 0.04$ (Pond 3) to $1.37 \pm 0.04 \mathrm{mg} / \mathrm{l}$ (Pond 1), and the values are higher than 0.005 to $0.25 \mathrm{mg} / \mathrm{l}$ (Anyanwu and Onyele, 2018) and $0.00013 \pm 0.00$ to $0.00017 \pm 0.00 \mathrm{mg} / \mathrm{l}$ (Ogbonna et al., 2018b) in related studies. The concentration of $\mathrm{Ni}$ in Pond 1 is 1.30, 1.33 and 27.40 times higher than its values in Pond 2, Pond 3 and control, respectively. The concentration of $\mathrm{Ni}(1.03 \pm 0.04$ to $1.37 \pm 0.04 \mathrm{mg} / \mathrm{l})$ in this study is higher than $1.0 \mathrm{mg} / \mathrm{l}(\mathrm{Ni})$ recommended by World Health Organization (WHO, 2003) and $0.01 \mathrm{mg} / \mathrm{l}(\mathrm{Ni})$ set by Standard Organization of Nigeria (SON, 2007) (Table 2). The concentration of Ni can pose serious health risk to quarry workers that usually use water from Pond 1 to clean their bodies after work during the dry season. Nickel cause lung, liver and kidney damage as well as cancer, respiratory failure, birth defects and heart failure (Adelekan and Abrgunde, 2011; Al Hagibi et al., 2018).

Table 1: Heavy metals $(\mathrm{mg} / \mathrm{kg})$ in pond water

\begin{tabular}{lllllll}
\hline Samples & $\mathrm{Pb}$ & $\mathrm{Cd}$ & $\mathrm{As}$ & $\mathrm{Ni}$ & $\mathrm{Fe}$ & $\mathrm{Zn}$ \\
\hline $\mathrm{P} 1$ & $7.87^{\mathrm{a}} \pm 1.08$ & $0.02^{\mathrm{a}} \pm 0.00$ & $2.35^{\mathrm{a}} \pm 0.09$ & $1.37^{\mathrm{a}} \pm 0.04$ & $4.18^{\mathrm{a}} \pm 0.04$ & $2.75^{\mathrm{a}} \pm 0.31$ \\
$\mathrm{P} 2$ & $6.70^{\mathrm{a}} \pm 0.78$ & $0.01^{\mathrm{b}} \pm 0.00$ & $2.08^{\mathrm{b}} \pm 0.04$ & $1.05^{\mathrm{b}} \pm 0.03$ & $3.90^{\mathrm{a}} \pm 0.15$ & $2.47^{\mathrm{a}} \pm 0.06$ \\
$\mathrm{P} 3$ & $7.47^{\mathrm{a}} \pm 0.71$ & $0.01^{\mathrm{b}} \pm 0.00$ & $1.99^{\mathrm{b}} \pm 0.02$ & $1.03^{\mathrm{b}} \pm 0.04$ & $3.66^{\mathrm{a}} \pm 0.44$ & $3.17^{\mathrm{a}} \pm 1.13$ \\
Control & $4.88^{\mathrm{a}} \pm 0.18$ & $0.001^{\mathrm{c}} \pm 0.00$ & $0.04^{\mathrm{b}} \pm 0.13$ & $0.05^{\mathrm{b}} \pm 0.04$ & $1.11^{\mathrm{b}} \pm 0.06$ & $1.21^{\mathrm{a}} \pm 0.06$ \\
\hline $\begin{array}{l}\text { Values are mean } \pm \text { standard deviation of 3 replicates } \\
\text { a,b,c,d,e } \text { Means in the same column with different superscripts are significantly different }(P<0.05)\end{array}$
\end{tabular}

Table 2: Comparison of concentration of heavy metals in pond water with international and national standards

\begin{tabular}{lllllllll}
\hline $\begin{array}{l}\text { Heavy } \\
\text { metals }\end{array}$ & This study & WHO & NDWQS & FEPA & FMEnv & $\begin{array}{l}\text { DPR } \\
2002\end{array}$ & $\begin{array}{l}\text { SON } \\
2007\end{array}$ & $\begin{array}{l}\text { USEPA } \\
2018\end{array}$ \\
\hline $\mathrm{Fe}$ & & 2011 & 2007 & 1991 & 2011 & 2002, \\
$\mathrm{Cd}$ & $3.66-4.18$ & 0.3 & 0.3 & 20 & 20 & 20 & 0.3 & 0.30 \\
$\mathrm{Ni}$ & $0.01-0.02$ & 0.003 & 0.003 & $>1.0$ & $0.03-0.3$ & $0.03-0.3$ & 0.003 & 0.001 \\
$\mathrm{Zn}$ & $1.03-1.37$ & 0.05 & $\mathrm{NA}$ & $0.02-0.10$ & $\mathrm{NA}$ & NA & 0.02 & 0.05 \\
$\mathrm{As}$ & $2.47-3.17$ & 3 & 3.0 & $<1.0$ & NA & 5 & 3.0 & 2 \\
$\mathrm{~Pb}$ & $1.99-2.35$ & 0.01 & 0.01 & 50 & NA & NA & NA & 0.05 \\
\hline
\end{tabular}

NA $=$ Not available

The value of As increased from $1.99 \pm 0.02$ (Pond 3) to $2.35 \pm 0.09 \mathrm{mg} / \mathrm{l}$ (Pond 1) and the values are higher than 0.00 to $0.010 \mathrm{mg} / \mathrm{l}$ in water samples from six (6) ponds at abandoned barite mine site in Cross River State, Nigeria (Adamu et al., 2015) and $0.003 \pm 0.001$ to $0.029 \pm 0.004 \mathrm{mg} / \mathrm{l}$ in water samples from surface and underground water sources at cement quarry site in Mfamosing in Akamkpa, Cross River State (Egbe et al., 2017). The concentration of As in Pond 1 is 1.13, 1.18 and 58.75 times higher than its values at Pond 2, Pond 3 and control, respectively. The concentration of As $(1.99 \pm 0.02$ to $2.35 \pm 0.09 \mathrm{mg} / \mathrm{l})$ is higher than the permissible limit of $0.01 \mathrm{mg} / \mathrm{l}$ (As) recommended by the World Health Organization (WHO, 2007). The high concentration of As in the pond water can be deleterious to the health of quarry workers and inhabitants of Ngwogwo that collect water from the ponds for domestic purposes. Similarly, the pond water may be a route of entry of contaminants such as heavy metals in plants when use for irrigation purposes by inhabitants of Ngwogwo during the dry season.

The highest concentration of $\mathrm{Pb}(7.87 \pm 1.08 \mathrm{mg} / \mathrm{l})$ and $\mathrm{Fe}(4.18 \pm 0.04 \mathrm{mg} / \mathrm{l})$ at the China quarry site were obtained in water sampled from Pond 1 but the values are not $(\mathrm{P}>0.05)$ significantly different from their corresponding values in Pond $2(6.70 \pm 0.78$ and $3.90 \pm 0.15 \mathrm{mg} / \mathrm{l})$, Pond $3(7.47 \pm 0.71$ and $3.66 \pm 0.44 \mathrm{mg} / \mathrm{l})$ and control $(4.88 \pm 0.18$ and $1.11 \pm 0.06 \mathrm{mg} / \mathrm{l})$. The concentration of $\mathrm{Pb}(7.87 \pm 1.08$ $\mathrm{mg} / \mathrm{l})$ at Pond 1 is 1.17, 1.05 and 1.61 times higher than its concentration at Pond 2, Pond 3 and control, respectively. The source of $\mathrm{Pb}$ and $\mathrm{Fe}$ may be attributed to dust from quarry activities as well as weathering and leaching of $\mathrm{Pb}$ and $\mathrm{Fe}$ compounds into the ponds. The concentration of $\mathrm{Pb}$ increased from $6.70 \pm 0.78$ (Pond 2) to $7.87 \pm 1.08 \mathrm{mg} / \mathrm{l}$ (Pond 1), and the values are higher than $0.26 \pm 0.01$ to $3.11 \pm 0.01 \mathrm{mg} / \mathrm{l}$ obtained in hand dug wells in Ishiagu in Ebonyi State (Akubugwo et al., 2012), $0.01 \mathrm{mg} / \mathrm{l}$ in selected water sources in Ekiti State (Oguntuase et al., 2019) and 0.01 to 0.72 $\mathrm{mg} / \mathrm{l}$ in rural spring in Umuariaga in Ikwuano, Abia State, Nigeria (Anyanwu and Onyele, 2018). The 
concentration of $\mathrm{Pb}$ in this study is higher than the permissible limit of $0.01 \mathrm{mg} / \mathrm{l}(\mathrm{Pb})$ recommended by the World Health Organization (WHO, 2003) and $1.0 \mathrm{mg} / \mathrm{l}(\mathrm{Pb})$ set by the Standard Organization of Nigeria (SON, 2007) (Table 2). The high concentration of $\mathrm{Pb}$ in the pond water can constitute serious health risk to animals that might drink from the ponds as well as the health of farmers that used the pond water for irrigation of their vegetable crops during the dry season. This, in turn, may result in bio-magnification of $\mathrm{Pb}$ in animals and people that will consume such metal contaminated crops. Exposure to $\mathrm{Pb}$ will affect the gastrointestinal tract, kidneys and the central nervous system (Tirkey et al., 2012), loss of memory, nausea, insomnia, anorexia, and weakness of the joints, failure of reproduction, inhibition of haemosynthesis, irritation and production of tumour (Adelekan and Abegunde, 2011). Lead ( $\mathrm{Pb}$ ) is a non-essential element and toxic in trace amount (Awofolu et al., 2005; Al Hagibi et al., 2018).

The concentration of Fe increased from 3.66 \pm 0.44 (pond 3) to $4.18 \pm 0.04 \mathrm{mg} / \mathrm{l}$ (pond 1), and the value is well below $2.12 \pm 0.01$ to $566.00 \pm 0.20 \mathrm{mg} / \mathrm{l}$ (Akubugwo et al., 2012) but relatively lower than 1.20 to $5.12 \mathrm{mg} / \mathrm{l}$ (Anyanwu and Onyele, 2018). The concentration of Fe in Pond 1 is 1.07, 1.14 and 3.77 times higher than its values at Pond 2, Pond 3 and control, respectively. The concentration of $\mathrm{Fe}$ in this study is higher than the permissible limit of $0.3 \mathrm{mg} / \mathrm{l}(\mathrm{Fe})$ recommended by World Health Organization (WHO, 2003) and the standard limit of $0.03 \mathrm{mg} / \mathrm{l}(\mathrm{Fe})$ set by Standard Organization of Nigeria (SON, 2007). Iron is essential to most life forms and to normal human physiology as well as integral part of many proteins and enzymes that maintain good health (Beard, 2000; Al Hagibi et al., 2018). It (Fe) is an essential component of proteins involved in oxygen transport and regulation of cell growth and differentiation (Dallman, 1986) and production of haemoglobin in red blood cells in human (Beldi et al., 2006). Notwithstanding this, excess amounts of Fe in human and animals can result in toxicity and even death (Al Hagibi et al., 2018).

The highest concentration of $\mathrm{Zn}(3.17 \pm 1.13 \mathrm{mg} / \mathrm{l})$ was obtained in Pond 3 but the value is not $(\mathrm{P}>$ $0.05)$ significantly different from values recorded for Pond $1(2.75 \pm 0.31 \mathrm{mg} / \mathrm{l})$ and Pond $2(2.47 \pm 0.06$ $\mathrm{mg} / \mathrm{l})$. The concentration of $\mathrm{Zn}$ in Pond 3 is $1.15,1.28$ and 2.62 times higher than its values in Pond 1 , Pond 2 and control, respectively. The concentration of $\mathrm{Zn}(2.47 \pm 0.06$ to $3.17 \pm 1.13 \mathrm{mg} / \mathrm{l})$ in this study is higher than $0.011 \pm 0.007$ to $0.046 \mathrm{mg} / \mathrm{l}$ in water quality characteristic of Rungiri quarry reservoir in Kiambu, Kenya (Kilonzo et al., 2019), 0.01 to $0.55 \mathrm{mg} / \mathrm{l}$ (Oguntuase et al., 2019) and 0.21 to 0.90 $\mathrm{mg} / \mathrm{l}$ (Anyanwu and Onyele, 2018) but well below $10.56 \pm 0.01$ to $217.55 \pm 0.51 \mathrm{mg} / \mathrm{l}$ (Akubugwo et al., 2012). The concentration of $\mathrm{Zn}$ in this study is relatively higher than the permissible limit of $3.0 \mathrm{mg} / \mathrm{l}$ (Zn) recommended by the World Health Organization (WHO, 2003). Zinc is an essential nutrient for human health (Hotz et al., 2003; Al Hagibi et al., 2018) but higher levels of Zn causes stomach cramps, vomiting, headaches, nausea, skin irritations, respiratory disorders, anaemia and loss of appetite (Rajappa et al., 2010). Generally, the order of abundance of heavy metals in pond water at China quarry site in Ngwogwo Ishiagu is as follows: $\mathrm{Pb}>\mathrm{Fe}>\mathrm{Zn}>\mathrm{As}>\mathrm{Ni}>\mathrm{Cd}$.

\subsection{Physico-chemical properties of pond water}

The results of the physic-chemical parameters of water sampled from ponds at China quarry site in Ngwogwo Ishiagu, Ebonyi State, Nigeria is summarized in Table 3. The result show that the highest values of total solid, TS $(427.09 \pm 0.90 \mathrm{mg} / \mathrm{l})$, total dissolved solid, TDS $(335.19 \pm 1.16 \mathrm{mg} / \mathrm{l})$ and biochemical oxygen demand, BOD $(53.15 \pm 0.86 \mathrm{mg} / \mathrm{l})$ were obtained in water samples collected from Pond 1 and the values were significantly $(\mathrm{P}<0.05)$ higher than their corresponding values in Pond 2 $(409.41 \pm 1.49,330.07 \pm 2.00$ and $45.30 \pm 3.06 \mathrm{mg} / \mathrm{l})$, Pond $3(401.58 \pm 1.57,328.26 \pm 1.35$ and $37.57 \pm 1.44$ and control $(189.70 \pm 4.51,223.75 \pm 3.35$ and $25.13 \pm 1.00 \mathrm{mg} / \mathrm{l})$, respectively for TS, TDS and BOD. Biochemical oxygen demand (BOD) is a measure of the quantity of oxygen used by micro-organisms (e.g. aerobic bacteria) in the oxidation of organic matter. The oxygen consumed in the decomposition process robs other aquatic organisms of the oxygen needed to live (Ogbonna et al., 2018b). The highest BOD recorded in Pond 1 may be attributed to high content of organic, inorganic and oxygen demanding pollutants present in the pond as well as low dissolved oxygen, DO $(5.14 \pm 1.51$ to $5.75 \pm 1.09 \mathrm{mg} / \mathrm{l})$ since low dissolved oxygen will result in high biochemical oxygen demand which is an indication of pollution (Tekenah et al., 2014). The result corroborate the findings of Oladiji et al. (2004), Amadi et al. (2006), Akan et al. (2008) and Akubugwo et al. (2012) that attributed their results to the presence of organic, inorganic and oxygen demanding pollutants in the water sources. The value of dissolved oxygen is relatively higher than $5.0 \mathrm{mg} / \mathrm{l}$ recommended by the World Health Organization (WHO, 2011) but lower than $20 \mathrm{mg} / \mathrm{l}$ (DO) recommended by Federal Environmental 
Protection Agency (FEPA, 1991) and $7.5 \mathrm{mg} / \mathrm{l}$ (DO) by Federal Ministry of Environment (FMEnv, 2011). The value of BOD in this study increased from $25.13 \pm 1.00$ at the control to $53.15 \pm 0.86 \mathrm{mg} / \mathrm{l}$ at Pond 1 , which is higher than $2.48 \pm 0.43$ to $20.74 \pm 2.22 \mathrm{mg} / \mathrm{l}$ obtained in hand dug wells in Ishiagu Ebonyi State (Akubugwo et al., 2012), 0.0405 to $0.0675 \mathrm{mg} / \mathrm{l}$ in water collected from Ubeyi River in Afikpo, Ebonyi State (Ogbonna et al., 2018b), 1.20 to $7.03 \mathrm{mg} / \mathrm{l}$ in water sampled from streams and Rivers in Abakiliki, Ebonyi State (Omaka et al., 2014) but lower than 56.60 \pm 0.21 to $158.40 \pm 5.76$ $\mathrm{mg} / \mathrm{l}$ obtained in water samples from Benue River (Anhwange et al., 2012). The value of BOD $(25.13 \pm 1.00$ to $53.15 \pm 0.86 \mathrm{mg} / \mathrm{l})$ in this study is well above the permissible limit of $3.0 \mathrm{mg} / \mathrm{l}$ (BOD) recommended by World Health Organization (WHO, 2011) and Federal Ministry of Environment (FMEnv, 2011) as well as $10 \mathrm{mg} / \mathrm{l}$ recommended by Federal Environmental Protection Agency (FEPA, 1991) (Table 4). Thus, the pond water at the China quarry site is polluted. Another evidence of pollution is the high level of total solids, TS $(189.70 \pm 4.51$ to $427.09 \pm 0.90 \mathrm{mg} / \mathrm{l}$. The values of total dissolved solids, TDS $(223.75 \pm 3.35$ to $335.19 \pm 1.16 \mathrm{mg} / \mathrm{l})$ and total suspended solids, TSS $(46.63 \pm 5.02$ to $115.68 \pm 1.59 \mathrm{mg} / \mathrm{l})$ which indicate materials carried in suspended form (Amadi et al., 2006; Akubugwo et al., 2012) falls within the permissible limits of 200 to $500 \mathrm{mg} / \mathrm{l}$ (TDS) and 80 to $150 \mathrm{mg} / \mathrm{l}$ (TSS) recommended by World Health Organization (WHO, 2003, 2011), respectively (Table 4). The values of TDS in this study is well below $2000 \mathrm{mg} / \mathrm{l}$ and $1000 \mathrm{mg} / \mathrm{l}$ (TDS) while the values of TSS is well above $30 \mathrm{mg} / \mathrm{l}$ and $25 \mathrm{mg} / \mathrm{l}$ recommended by Federal Environmental Protection Agency (FEPA, 1991) and National Drinking Water Quality Standard (NDWQS, 2007), respectively (Table 4). The value of $\mathrm{pH}$ in water sampled from the ponds range from $6.86 \pm 0.11$ to $7.39 \pm 0.01$ which is slightly acidic to alkaline. This may be attributed to the decomposition of organic material that has buffering effect in the water. The highest value of $\mathrm{pH}(7.39 \pm 0.01)$ was recorded for pond 1 and the value is not different $(\mathrm{P}>0.05)$ from the value obtained in Pond 2 (7.20 \pm 0.10$)$ but significantly $(\mathrm{P}<0.05)$ higher than values recorded for Pond $3(6.86 \pm 0.11)$ and control $(6.23 \pm 0.19)$, respectively. The $\mathrm{pH}$ of water samples from Pond $1(7.39 \pm 0.01)$ and $2(7.20 \pm 0.10)$ is within the alkaline range and this result corroborate with the findings of Nwachukwu et al. (2018) that reported similar $\mathrm{pH}$ value $(7.52 \pm 0.11)$ in their study of critical issues of sustainability associated with quarry activities in Iyuku community in Auchi, Edo State of Nigeria. The values of $\mathrm{pH}(6.86 \pm 0.11$ to $7.39 \pm 0.01$ ) in this study is relatively lower than $6.43 \pm 0.06$ to $7.67 \pm 0.06$ obtained in water samples collected from hand dug wells in Ishiagu, Ebonyi State (Akubugwo et al., 2012), 6.88 to 7.75 in selected water sources in Ekiti State, Nigeria (Oguntuase et al., 2019) but higher than $6.38 \pm 0.07$ to $6.53 \pm 6.53$ (Ekweozor et al., 2017). The value of $\mathrm{pH}$ in this study fall within the 6.5 to 8.5 recommended by World Health Organization (WHO, 2003) and 6-9 established by Federal Ministry of Environment (FMEnv, 2011) (Table 4).

Table 3: Physicochemical properties of pond water

\begin{tabular}{|c|c|c|c|c|c|c|c|c|c|}
\hline Samples & $\mathrm{pH}$ & TA (mg/l) & $\mathrm{TS}(\mathrm{mg} / \mathrm{l})$ & TDS (mg/l) & TSS (mg/l) & DO (mg/l) & COD (mg/l) & $\mathrm{BOD}(\mathrm{mg} / \mathrm{l})$ & Temperature ${ }^{\circ} \mathrm{C}$ \\
\hline P1 & $7.39^{\mathrm{a}} \pm 0.01$ & $104.10^{\mathrm{a}} \pm 1.08$ & $427.09^{\mathrm{a}} \pm 0.90$ & $335.19^{\mathrm{a}} \pm 1.16$ & $115.68^{\mathrm{a}} \pm 1.59$ & $5.75^{\mathrm{a}} \pm 1.09$ & $61.28^{\mathrm{a}} \pm 0.64$ & $53.15^{\mathrm{a}} \pm 0.86$ & $30.67^{\mathrm{a}} \pm 0.64$ \\
\hline $\mathrm{P} 2$ & $7.20^{\mathrm{a}} \pm 0.10$ & $102.07^{\mathrm{a}} \pm 1.05$ & $409.41^{\mathrm{b}} \pm 1.49$ & $330.07^{\mathrm{b}} \pm 2.00$ & $114.47^{\mathrm{a}} \pm 1.22$ & $5.68^{\mathrm{a}} \pm 0.94$ & $60.40^{\mathrm{ab}} \pm 0.53$ & $45.30^{\mathrm{b}} \pm 3.06$ & $30.42^{\mathrm{a}} \pm 0.37$ \\
\hline P3 & $6.86^{\mathrm{b}} \pm 0.11$ & $96.30^{\mathrm{b}} \pm 2.15$ & $401.58^{\mathrm{c}} \pm 1.57$ & $328.26^{\mathrm{c}} \pm 1.35$ & $111.48^{\mathrm{a}} \pm 0.36$ & $5.14^{\mathrm{a}} \pm 1.51$ & $59.55^{\mathrm{b}} \pm 0.51$ & $37.57^{\mathrm{c}} \pm 1.44$ & $30.32^{\mathrm{a}} \pm 114$ \\
\hline Control & $6.23^{\mathrm{c}} \pm 0.19$ & $85.37^{\mathrm{b}} \pm 1.48$ & $189.70^{\mathrm{d}} \pm 4.51$ & $223.75^{\mathrm{c}} \pm 3.35$ & $46.63^{\mathrm{a}} \pm 5.02$ & $18.06^{\mathrm{a}} \pm 2.13$ & $20.37^{\mathrm{b}} \pm 0.55$ & $25.13^{\mathrm{d}} \pm 1.00$ & $28.43^{\mathrm{a}} \pm 1.25$ \\
\hline
\end{tabular}

Values are mean \pm standard deviation of 3 replicates

$a, b, c, d, e$ Means in the same column with different superscripts are significantly different $(P<0.05)$

Table 4: Comparison with international and national standards

\begin{tabular}{lllllllll}
\hline Parameters & This study & WHO 2003, & NDWQS & FEPA & FMEnv & DPR & SON & USEPA \\
& & 2011 & 2007 & 1991 & 2011 & 2002 & 2007 & 2018 \\
\hline pH & $6.86-7.39$ & $6.5-8.5$ & $6.5-8.5$ & $6-9$ & $6-9$ & $6.5-8.5$ & $6.5-8.5$ & NA \\
TA & $96.30-104.10$ & 200 & NA & NA & NA & NA & NA & NA \\
TS & $401.58-427.09$ & 500 & NA & NA & NA & NA & NA & NA \\
TDS & $328.26-335.19$ & $200-500$ & 1000 & 2000 & NA & NA & 500 & NA \\
TSS & $111.48-115.68$ & $80-150$ & 25 & 30 & 50 & 50 & NA & NA \\
DO & $5.14-5.75$ & 5 & NA & 20 & 7.50 & NA & NA & NA \\
COD & $59.55-61.28$ & 7.5 & NA & 30 & NA & NA & NA & NA \\
BOD & $37.57-53.13$ & 3.0 & NA & 10 & 3 & 3 & NA & $\geq 10$ \\
Temp & $30.32-30.67$ & $25-30^{\circ} \mathrm{C}$ & NA & $30^{\circ} \mathrm{C}$ & $<40^{\circ} \mathrm{C}$ & NA & NA & NA \\
\hline
\end{tabular}

NA = Not available

Total alkalinity (TA) is highest in Pond $1(104.10 \pm 1.08 \mathrm{mg} / \mathrm{l})$ but the value is not different $(\mathrm{P}>0.05)$ from the value recorded for Pond $2(102.07 \pm 1.05 \mathrm{mg} / \mathrm{l})$ but it is significantly $(\mathrm{P}<0.05)$ higher than values obtained in Pond $3(96.30 \pm 2.15 \mathrm{mg} / \mathrm{l})$ and control $(85.37 \pm 1.48 \mathrm{mg} / \mathrm{l})$. The value of total 
alkalinity range from $96.30 \pm 2.15$ to $104.10 \pm 1.08 \mathrm{mg} / \mathrm{l}$ which is lower than $36.67 \pm 1.53$ to $335.00 \pm 1.00$ $\mathrm{mg} / \mathrm{l}$ reported by Akubugwo et al. (2012) but well above 1.0 to $1.3 \mathrm{mg} / \mathrm{l}$ (Oguntuase et al., 2019). The value of total alkalinity in this study is well below the $200 \mathrm{mg} / \mathrm{l}$ (TA) recommended by World Health Organization (WHO, 2011). Chemical oxygen demand (COD) is the amount of oxygen consumed to chemically oxidize organic water contaminants to inorganic end products. The highest COD $(61.28 \pm 0.64 \mathrm{mg} / \mathrm{l})$ is obtained in Pond 1 but the value is statistically $(\mathrm{P}>0.05)$ the same with value obtained in Pond $2(60.40 \pm 0.53 \mathrm{mg} / \mathrm{l})$ but significantly $(\mathrm{P}<0.05)$ higher than values recorded for Pond $3(59.55 \pm 0.51 \mathrm{mg} / \mathrm{l})$ and control $(20.37 \pm 0.55 \mathrm{mg} / \mathrm{l})$. The value of COD in this study is well above the $7.5 \mathrm{mg} / \mathrm{l}$ (COD) recommended by World Health Organization (WHO, 2003) and $30 \mathrm{mg} / \mathrm{l}$ (COD) recommended by Federal Environmental Protection Agency (FEPA, 1991) (Table 4). The value of COD increased from $59.55 \pm 0.51$ to $61.28 \pm 0.64 \mathrm{mg} / \mathrm{l}$ at China quarry site and the value is lower than $2.48 \pm 0.43$ to $112.00 \pm 8.00 \mathrm{mg} / \mathrm{l}$ reported by Akubuqwo et al. (2012). The values of temperature in the three water ponds sampled at China quarry site did not differ significantly $(\mathrm{P}>$ 0.05 ) from one another. The temperature range from $30.32 \pm 1.14$ (pond 3 ) to $30.67 \pm 0.64{ }^{\circ} \mathrm{C}$ (pond 1 ) which is relatively higher than 26.3 to $27.1^{\circ} \mathrm{C}$ (Oguntuase et al., 2019), $27.37 \pm 0.21$ to $28.7 \pm 0.26^{\circ} \mathrm{C}$ (Ekweozor et al., 2017) but relatively lower than $29.27 \pm 0.05$ to $30.90 \pm 0.00{ }^{\circ} \mathrm{C}$ (Akubugwo et al., 2012). The values of temperature in this study is relatively above 25 to $30^{\circ} \mathrm{C}$ (temp) recommended by World Health Organization (WHO, 2003). Generally, the order of abundance of the physic-chemical parameters is as follows: $\mathrm{TS}>\mathrm{TDS}>\mathrm{TSS}>\mathrm{TA}>\mathrm{COD}>\mathrm{BOD}>$ Temperature $>\mathrm{pH}>\mathrm{DO}$.

\subsection{Macronutrient content in pond water}

Table 5 summarized the result of macronutrient content in pond water at China quarry site in Ngwogwo, Ishiagu in Ebonyi State, Nigeria. The result indicate that significant differences exist among the means of the parameters (e.g. $\mathrm{K}, \mathrm{Mg}$ and $\mathrm{Ca}$ ) tested in the water samples collected from the three (3) ponds (P1, P2 and P3) at China quarry and control. The highest and lowest values of macronutrient in water samples were observed in water from the quarry ponds and control sites, respectively. From the result in Table 5, the highest values of $\mathrm{K}(1.78 \pm 0.08 \%), \mathrm{Mg}(3.99 \pm 0.01 \%)$ and $\mathrm{Ca}(102.83 \pm 0.59 \%)$ were obtained in water samples collected from Pond 1 and their values are higher than their corresponding values in Pond $2(1.15 \pm 0.16,2.11 \pm 0.01$ and $92.18 \pm 1.31 \%)$, Pond 3 $(0.99 \pm 0.01,2.06 \pm 0.04$ and $91.88 \pm 0.18 \%)$ and control $(0.06 \pm 0.04,0.98 \pm 0.03$ and $12.15 \pm 1.05 \%)$. The high values of $\mathrm{K}, \mathrm{Mg}$ and $\mathrm{Ca}$ in Pond 1 may be attributed to deposition of dust particles from China quarry activities since these element $(\mathrm{K}, \mathrm{Mg}$ and $\mathrm{Ca}$ ) are part of the composition of granite (Table 6) vis-à-vis the leaching of the element into Pond 1 via runoff as well as infiltration from the bottom of the pond. The value of $\mathrm{K}(1.78 \pm 0.08 \%)$ in water samples from Pond 1 is $1.55,1.80$ and 29.67 times higher than its corresponding values in Pond 2, Pond 3 and control, respectively. The values of $\mathrm{K}$ in water sample increased from $0.99 \pm 0.01$ at Pond 3 to $1.78 \pm 0.08 \%$ at Pond 1 , and the values is higher than 0.0022 to $0.0045 \%$ in pond water in quarry site in Akure, Ondo State, Nigeria (Akande and Jimoh, 2013) as well as 200 and $50 \mathrm{mg} / \mathrm{l}(\mathrm{K})$ recommended by World Health Organization, (WHO, 2011) and Federal Ministry of Environment (FMEnvi, 2011), respectively (Table 7). The value of Mg $(3.99 \pm 0.01 \%)$ in water samples from Pond 1 is $1.89,1.94$ and 4.07 times higher than its corresponding values in Pond 2, Pond 3 and control, respectively. The values of $\mathrm{Mg}$ in the water samples from China quarry site increased from $2.06 \pm 0.04$ in Pond 3 to $3.99 \pm 0.01 \%$ in Pond 1 , and the values are higher than 0.00 to $0.0150 \%$ reported in pond water in a quarry site in Akure, Ondo State State, Nigeria (Akande and Jimoh, 2013). Also, the values of Mg in this study is well above the permissible limit of $50 \mathrm{mg} / \mathrm{l}(\mathrm{Mg})$ recommended by World Health Organization, (WHO, 2011) and 40 mg/l (Mg) recommended by Federal Ministry of Environment (FMEnvi, 2011) (Table 7).

Table 5: Macronutrients in pond water

\begin{tabular}{lllllll}
\hline Samples & $\mathrm{Mn}(\%)$ & $\mathrm{K}(\%)$ & $\mathrm{Na}(\%)$ & $\mathrm{Mg}(\%)$ & $\mathrm{Ca}(\%)$ & $\mathrm{Co}(\%)$ \\
\hline P1 & $5.10^{\mathrm{a}} \pm 1.27$ & $1.78^{\mathrm{a}} \pm 0.08$ & $0.99^{\mathrm{a}} \pm 0.08$ & $3.99^{\mathrm{a}} \pm 0.01$ & $102.83^{\mathrm{a}} \pm 0.59$ & $14.14^{\mathrm{a}} \pm 1.33$ \\
P2 & $4.29^{\mathrm{a}} \pm 1.10$ & $1.15^{\mathrm{b}} \pm 0.16$ & $0.92^{\mathrm{a}} \pm 0.04$ & $2.11^{\mathrm{b}} \pm 0.01$ & $92.18^{\mathrm{b}} \pm 1.31$ & $12.23^{\mathrm{a}} \pm 1.38$ \\
P3 & $3.64^{\mathrm{a}} \pm 0.91$ & $0.99^{\mathrm{b}} \pm 0.01$ & $0.85^{\mathrm{a}} \pm 0.13$ & $2.06^{\mathrm{b}} \pm 0.04$ & $91.88^{\mathrm{b}} \pm 0.18$ & $12.15^{\mathrm{a}} \pm 1.05$ \\
Control & $1.48^{\mathrm{a}} \pm 0.74$ & $0.06^{\mathrm{b}} \pm 0.04$ & $0.28^{\mathrm{a}} \pm 0.04$ & $0.98^{\mathrm{c}} \pm 0.03$ & $12.15^{\mathrm{c}} \pm 1.05$ & $4.46^{\mathrm{a}} \pm 0.72$ \\
\hline
\end{tabular}

Values are mean \pm standard deviation of 3 replicates

$a, b, c, d, e$ Means in the same column with different superscripts are significantly different $(P<0.05)$ 
Table 6: Macronutrient content in granite chippings

\begin{tabular}{lllcccc}
\multicolumn{1}{c}{ Samples } & \multicolumn{1}{c}{$\mathrm{Ca}(\%)$} & \multicolumn{1}{c}{$\mathrm{Mg}(\%)$} & $\mathrm{K}(\%)$ & $\mathrm{Na}(\%)$ & $\mathrm{Co}(\%)$ & $\mathrm{Mn}(\mathrm{mg} / \mathrm{kg})$ \\
\hline Dust & $5.41^{\mathrm{a}} \pm 0.01$ & $3.23^{\mathrm{ab}} \pm 0.01$ & $0.24^{\mathrm{a}} \pm 0.02$ & $0.42^{\mathrm{a}} \pm 0.00$ & $1.40^{\mathrm{e}} \pm 0.04$ & $94.21^{\mathrm{a}} \pm 0.13$ \\
0.50 (unmixed) & $5.32^{\mathrm{ab}} \pm 0.01$ & $3.16^{\mathrm{d}} \pm 0.00$ & $0.13^{\mathrm{d}} \pm 0.00$ & $0.29 \mathrm{c} \pm 0.02$ & $1.72^{\mathrm{b}} \pm 0.01$ & $90.68^{\mathrm{e}} \pm 0.00$ \\
0.50 (mixed) & $5.36^{\mathrm{ab}} \pm 0.06$ & $3.20^{\mathrm{bcd}} \pm 0.01$ & $0.22^{\mathrm{a}} \pm 0.01$ & $0.41^{\mathrm{a}} \pm 0.00$ & $1.92^{\mathrm{a}} \pm 0.02$ & $93.20^{\mathrm{b}} \pm 0.27$ \\
$3 / 8$ inch & $5.28^{\mathrm{bc}} \pm 0.08$ & $3.11^{\mathrm{e}} \pm 0.01$ & $0.18^{\mathrm{b}} \pm 0.01$ & $0.41^{\mathrm{a}} \pm 0.00$ & $1.54^{\mathrm{d}} \pm 0.08$ & $90.43^{\mathrm{e}} \pm 0.11$ \\
$3 / 4$ inch & $5.20^{\mathrm{cd}} \pm 0.01$ & $3.17^{\mathrm{cd}} \pm 0.00$ & $0.15^{\mathrm{c}} \pm 0.00$ & $0.41^{\mathrm{a}} \pm 0.01$ & $1.36^{\mathrm{e}} \pm 0.01$ & $91.55^{\mathrm{d}} \pm 0.35$ \\
$1 / 2$ inch & $5.00^{\mathrm{e}} \pm 0.00$ & $3.21^{\mathrm{bc}} \pm 0.02$ & $0.14^{\mathrm{cd}} \pm 0.01$ & $0.40^{\mathrm{a}} \pm 0.00$ & $1.40^{\mathrm{e}} \pm 0.01$ & $92.23^{\mathrm{c}} \pm 0.32$ \\
1 inch & $5.11^{\mathrm{de}} \pm 0.09$ & $3.36^{\mathrm{a}} \pm 0.04$ & $0.14^{\mathrm{cd}} \pm 0.00$ & $0.42^{\mathrm{a}} \pm 0.01$ & $1.62^{\mathrm{c}} \pm 0.01$ & $92.17^{\mathrm{cd}} \pm 0.33$ \\
Hardcore & $4.42^{\mathrm{f}} \pm 0.00$ & $3.04^{\mathrm{f}} \pm 0.00$ & $0.23^{\mathrm{a}} \pm 0.00$ & $0.33^{\mathrm{b}} \pm 0.01$ & $1.53^{\mathrm{d}} \pm 0.01$ & $84.80^{\mathrm{f}} \pm 0.42$ \\
\hline
\end{tabular}

Source: Ogbonna et al. (2020c)

Values are mean \pm standard deviation of 3 replicates

${ }_{a, b, c, d, e}$ Means in the same column with different superscripts are significantly different $(P<0.05)$

Table 7: Comparison of macro elements content in pond water with international and national standards

\begin{tabular}{lllllllll}
\hline Macronutrient & This study & WHO 2003, & NDWQS & FEPA 1991 & FMEnv & DPR & SON 2007 & USEPA \\
& & 2011 & 2007 & & 2011 & 2002 & & 2018 \\
\hline $\mathrm{K}$ & $0.99-1.78$ & 200 & NA & NA & 50 & NA & NA & NA \\
$\mathrm{Na}$ & $0.85-0.99$ & 200 & NA & NA & 120 & NA & 200 & NA \\
$\mathrm{Ca}$ & $91.88-102.83$ & 100 & NA & NA & 180 & NA & NA & NA \\
$\mathrm{Mg}$ & $2.06-3.99$ & 50 & 150 & NA & 40 & NA & NA & NA \\
$\mathrm{Mn}$ & $3.64-5.10$ & 0.5 & 0.2 & $0.02-0.10$ & NA & NA & 0.05 & 0.05 \\
$\mathrm{Co}$ & $12.15-14.14$ & NA & NA & NA & NA & NA & NA & NA \\
\hline
\end{tabular}

The value of $\mathrm{Ca}(102.83 \pm 0.59 \%)$ in water samples from Pond 1 is $1.12,1.12$ and 8.46 times higher than its corresponding values in Pond 2, Pond 3 and control, respectively. The values of $\mathrm{Ca}$ in the water samples at China quarry site increased from $91.88 \pm 0.18$ in Pond 3 to $102.83 \pm 0.59 \%$ in Pond 1 , and the values are higher than 0.00 to $0.0200 \%$ obtained in pond water samples in a quarry site in Akure, Ondo State, Nigeria (Akande and Jimoh, 2013) and 0.19116911 to $0.22470230 \%$ obtained in surface water of Kenyir Lake, Malaysia (Hussain and Abdullah, 2018) (Table 8). The values of Ca in this study is higher than $100 \mathrm{mg} / \mathrm{l}(\mathrm{Ca})$ recommended by World Health Organization (WHO, 2011) and $180 \mathrm{mg} / \mathrm{l}(\mathrm{Ca})$ recommended by Federal Ministry of Environment (FMEnvi, 2011) (Table 7). The highest values of $\mathrm{Mn}(5.10 \pm 1.27 \%), \mathrm{Na}(0.99 \pm 0.08 \%)$ and $\mathrm{Co}(14.14 \pm 1.33 \%)$ were obtained in water samples collected from Pond 1 but the values are not significantly $(\mathrm{P}>0.05)$ different from their corresponding values in Pond $2(4.29 \pm 1.10,0.92 \pm 0.04$ and $12.23 \pm 1.38 \%)$ and Pond 3 $(3.64 \pm 0.91,0.85 \pm 0.13$ and $12.15 \pm 1.05 \%)$ but significantly higher than values in control $(1.48 \pm 0.74$, $0.28 \pm 0.04$ and $4.46 \pm 0.72 \%)$. The value of $\mathrm{Mn}(5.10 \pm 1.27 \%)$ in water samples from Pond 1 is 1.19 , 140 and 3.45 times higher than its corresponding values in Pond 2, Pond 3 and control, respectively. The values of Mn increased from 3.64 \pm 0.91 in Pond 3 to 5.10 $\pm 1.27 \%$ in Pond 1, and the values are higher than 0.41 to $1.02 \%$ in pond water samples around Aviation quarry Zaria, Kaduna State, Nigeria (Chia et al., 2011), 0.000009 to $0.000084 \%$ in pond water in a quarry (Garba et al., 2019) and BDL to $0.00000 \%$ in quarry pond at Isinigbo/Igoba in Akure, Ondo State (Akande and Jimoh, 2013). Similarly, the values of $\mathrm{Mn}$ in this study is higher than $0.5 \mathrm{mg} / \mathrm{l}(\mathrm{Mn})$ recommended by World Health Organization, (WHO, 2011), $0.2 \mathrm{mg} / \mathrm{l}(\mathrm{Mn})$ recommended by Standard Organization of Nigeria (SON, 2007) and 0.02 to $0.10 \mathrm{mg} / \mathrm{l}(\mathrm{Mn})$ by Federal Environmental Protection Agency (FEPA, 1991) (Table 7). The value of $\mathrm{Na}(0.99 \pm 0.08 \%)$ in water samples from Pond 1 is $1.08,1.16$ and 8.54 times higher than its corresponding values in Pond 2, Pond 3 and control, respectively. The values of $\mathrm{Na}$ increased from $0.85 \pm 0.13$ in Pond 3 to $0.99 \pm 0.08 \%$ in Pond 1 , and the values are well above $200 \mathrm{mg} / \mathrm{l}(\mathrm{Na})$ recommended by World Health Organization, (WHO, 2011), $120 \mathrm{mg} / \mathrm{l}$ (Na) recommended by Federal Ministry of Environment (FMEnv, 2011) and $200 \mathrm{mg} / \mathrm{l}$ (Na) recommended by Standard Organization of Nigeria (SON, 2007) (Table 7). Similarly the values of $\mathrm{Na}$ in this study are above 0.00205 to $0.00300 \%$ in quarry ponds in Lokpa-Ukwu and Lekwesi in Umunneochi, Abia State, Nigeria (Mbaneme et al., 2018) and 0.00000 to $0.000102 \mathrm{mg} / \mathrm{l}$ in quarry pond in Akure (Akande and Jimoh, 2013). The value of Co $(14.14 \pm 1.33 \%)$ in water samples from Pond 1 is 1.16, 1.16 and 3.17 times higher than its corresponding values in Pond 2, Pond 3 and control, respectively. The values of Co increased from $12.15 \pm 1.05$ in Pond 3 to $14.14 \pm 1.33 \%$ in Pond 3, and the values are higher than 0.18 to $1.85 \%$ in pond water samples around Aviation quarry Zaria, Kaduna State, Nigeria (Chia et al., 2011). The order abundance of macronutrient in pond water is in the increasing order: $\mathrm{Na}<\mathrm{K}<\mathrm{Mg}<\mathrm{Mn}<\mathrm{Co}<\mathrm{Ca}$. 
Table 8: Comparison with related studies

\begin{tabular}{|c|c|c|c|c|c|c|c|}
\hline & This study & $\begin{array}{l}\text { Hussain and Abdullah } \\
\text { (2018) }\end{array}$ & $\begin{array}{l}\text { Chia et al. } \\
\text { (2011) }\end{array}$ & $\begin{array}{l}\text { Osakwe and } \\
\text { Asuquo } \\
(2017)\end{array}$ & $\begin{array}{l}\text { Ayoade and } \\
\text { Nathaniel } \\
(2018)\end{array}$ & $\begin{array}{l}\text { Omotosho et } \\
\text { al. }(2019)\end{array}$ & $\begin{array}{l}\text { Enuneku et } \\
\text { al. } \\
2017\end{array}$ \\
\hline $\mathrm{Fe}$ & $3.66-4.18$ & $27.4709-52.4427$ & ND & ND & $0.35-1.37$ & $22.39-24.03$ & ND \\
\hline $\mathrm{Cd}$ & $0.01-0.02$ & ND & ND & ND & $0.02-0.04$ & $1.80-2.40$ & ND \\
\hline $\mathrm{Ni}$ & $1.03-1.37$ & $0.1699-0.7388$ & ND & ND & $0.05-0.15$ & ND & ND \\
\hline $\mathrm{Zn}$ & $2.47-3.17$ & $1.0255-2.5341$ & ND & ND & $0.03-0.09$ & $1.20-2.20$ & ND \\
\hline As & $1.99-2.35$ & $0.2564-0.3556$ & ND & ND & ND & ND & ND \\
\hline $\mathrm{Pb}$ & $6.70-7.87$ & ND & ND & ND & $0.04-0.13$ & $0.42-0.97$ & ND \\
\hline $\mathrm{pH}$ & $6.86-7.39$ & $6.84-7.13$ & $5.9-8.3$ & $7.13-8.15$ & $7.53-7.59$ & $6.30-9.00$ & $6.12-6.31$ \\
\hline TA & $96.30-104.10$ & ND & 17.0 & ND & $39.14-46.05$ & ND & $9.87-16.13$ \\
\hline TS & $401.58-427.09$ & ND & ND & $142-426$ & ND & $1292-2704$ & $15.29-23.70$ \\
\hline TDS & $328.26-335.19$ & $15.93-16.71$ & 209 & $132-430$ & $249.96-264.94$ & $1537.2-3472.5$ & $7.42-19.43$ \\
\hline TSS & $111.48-115.68$ & $1.28-4.44$ & ND & $12.3-13.9$ & $0.77-0.80$ & $206-420$ & $4.93-9.73$ \\
\hline DO & $5.14-5.75$ & $2.28-6.88$ & 5.35 & $6.79-8.48$ & $4.23-6.34$ & $3.50-5.20$ & $2.04-4.27$ \\
\hline $\mathrm{COD}$ & $59.55-61.28$ & $4.70-8.20$ & ND & $19.94-32.68$ & & $120-195$ & ND \\
\hline BOD & $37.57-53.13$ & $0.77-1.13$ & 1.70 & $6.14-7.61$ & $2.81-4.44$ & $65-85$ & $1.23-1.93$ \\
\hline Temp & $30.32-30.67$ & $30.91-31.40$ & $26.9-28.7$ & ND & $28.45-31.22$ & $20-32$ & $25.38-26.18$ \\
\hline $\mathrm{K}$ & $0.99-1.78$ & $891.1032-950.8119$ & ND & $4.01-6.68$ & $5.62-7.40$ & ND & ND \\
\hline $\mathrm{Na}$ & $0.85-0.99$ & ND & ND & $3.51-4.27$ & ND & ND & ND \\
\hline $\mathrm{Ca}$ & $91.88-102.83$ & $1911.6911-2247.0230$ & ND & $8.30-18.9$ & ND & ND & $1.81-2.03$ \\
\hline $\mathrm{Mg}$ & $2.06-3.99$ & $430.8243-517.3665$ & ND & $41.2-54.6$ & ND & ND & $1.17-1.52$ \\
\hline $\mathrm{Mn}$ & $3.64-5.10$ & $4.2531-5.5967$ & ND & ND & $0.50-1.29$ & ND & ND \\
\hline Co & $12.15-14.14$ & ND & ND & ND & $0.03-0.04$ & ND & ND \\
\hline
\end{tabular}

\subsection{Conclusions}

The results of the analysis of pond water from China quarry site indicate that quarrying is a potential source of contaminants to aquatic bodies. The concentrations of the potentially toxic element such as $\mathrm{Cd}, \mathrm{Pb}, \mathrm{Ni}, \mathrm{As}, \mathrm{Fe}$ and $\mathrm{Zn}$ are higher than the permissible limits recommended by the World Health Organization (WHO) and Standard Organization of Nigeria (SON). Similarly, the values of biochemical oxygen demand (BOD), chemical oxygen demand (COD), and Mn are higher than the permissible limit of World Health Organization (WHO) and Federal Environmental Protection Agency, FEPA. The values of DO and Ca are higher than the permissible limit of WHO while the value of TSS is higher than the permissible limit of FEPA. Thus, the workers at China quarry site and the inhabitants of Ngwogwo use water from polluted ponds. Therefore, it is recommended that quarry workers and inhabitants of Ngwogwo should be discouraged from making use of water from the ponds for domestic purposes and irrigation of crops during dry season. More so, Ebonyi State Government should demand comprehensive Environmental Impact Assessment (EIA) report from quarry operators before issuing operating license to them.

\section{Acknowledgement}

The authors acknowledge the Manager of China quarry for giving access to the various sampling positions in this study. The services of Mr. Emebu, Propsper Kome (statistical analysis of the data) are also appreciated.

\section{Conflict of Interest}

There is no conflict of interest associated with this work.

\section{References}

Adamu, C.I., Nganje, T.N. and Edet, A. (2015). Heavy metal contamination and health risk assessment associated with abandoned barite mines in Cross River State, southeastern Nigeria. Environmental Nanotechnology, Monitoring and Management, 3, pp. 10-21.

Adelekan, B. A., and Abegunde, K. D. (2011). Heavy metals contamination of soil and groundwater at automobile mechanic villages in Ibadan, Nigeria. International Journal of the Physical Sciences, 6(5), pp. 1045-1058.

Afiukwa, J.N. and Eboatu, A.N. (2013). Analysis of spring water quality in Ebonyi South Zone and its health impact. American Journal of Scientific and Industrial Research, 4(2), pp. 231-237. 
Agency for Toxic Substances and Disease Registry, ATSDR (2008). ATSDR Medical Fact Sheet; Division of Toxicology and Environmental Medicine ToxFAQs; Accessed November 19, 2010. http://www.atsdr.cdc.gov/tfacts5.pdf.

Akan, J.C., Abdulraham, F.I., Dimari, G.A. and Ogugbuaja, V.O. (2008). Physicochemical determination of pollutants in wastewater and vegetable samples along the Jakava wastewater channelin Kano metropolis Kano State, Nigeria. European Journal of Scientific Research, 23, pp. 122-133.

Akande, J.M. and Jimoh, B.O. (2013). Quarrying of sand and proposed reclamation method in Akure, Nigeria. International Journal of Engineering and Technology, 3(7), pp. 746-757.

Akubugwo, E.I., Ude, V.C., Uhuegbu, F.O. and Ugbogu, O. (2012). Physicochemical properties and heavy metal content of selected water sources in Ishiagu, Ebonyi State- Nigeria. Journal of Biodiversity and Environmental Sciences, 2(2), pp. 21-27.

Al Hagibi, H.A., Al-Selwi K.M., Nagi H.M. and Al-Shwafi, N.A. (2018). Study of heavy metals contamination in mangrove sediments of the Red Sea coast of Yemen from Al-Salif to Bab-elMandeb Strait. Journal of Ecology and Natural Resources, 2(1), pp. 121-138.

Aloke, C., Uzuegbu, I.E., Ogbu, P.N., Ugwuja, E.I., Orinya, O.F., et al. (2019). Comparative assessment of heavy metals in drinking water sources from Enyigba Community in Abakaliki Local Government Area, Ebonyi State, Nigeria. African Journal of Environmental Science and Technology, 13(4), pp. 149-154.

Amadi, B.A., Chikezie, P.C. and Okeoma, H.C. (2006). Physicochemical characteristics of Nworie River and its Effect on liver function of rats. Journal of Nigerian Environmental Society, 3, pp.183187.

Anhwange, B.A., Agbaji, E.B. and Gimba, E.C. (2012). Impact Assessment of Human Activities and Seasonal Variation on River Benue, within Makurdi Metropolis. International Journal of Science and Technology, 2(5), pp. 248-254.

Ani, C., Okogwu, O.I., Nwonumara, G.N., Nwani, C.D. and Nwinyimagu, A.J. (2016). Evaluation of physicochemical parameters of selected rivers in Ebonyi State, Southeast, Nigeria. Greener Journal of Biological Sciences, 6(2), pp. 34-41.

Anyanwu, E.D. and Onyele, O.G. (2018). Occurrence and concentration of heavy metals in a rural spring in South-eastern Nigeria. Journal of Applied Sciences and Environ. Management, 22(9), pp. $1473-1478$.

APHA (1998). Standard Methods for the Examination of Water and Wastewater, 17th edition, Washington D.C. pp. 1269-1280.

Asklund, R. and Eldvall, B. (2005). Contamination of water resources in Tarkwa mining area of Ghana. Department of Engineering Geology, Lund University, Sweden.

Atkins, M.L., Santos, I.R., Perkins, A. and Maher, D.T. (2016). Dissolved radon and uranium in groundwater in a potential coal seam gas development region (Richmond River Catchment, Australia). Journal of Environmental Radioactivity, 154, pp. 83-92.

Awofolu, O.R., Mbolekwa, Z., Mtshemla, V. and Fatoki, O.S. (2005). Levels of trace metals in water and sediment from Tyume River and its effects on an irrigated farmland. Water SA, 31(1), pp. 87-94.

Ayoade A. A. and Nathaniel O. G (2018). Assessment of heavy metals contamination of surface water and sediment of a tropical manmade Lake Southwestern Nigeria. International Journal of Environment and Pollution Research, 6(3), pp. 1-16.

Babatunde, O.A. and Umahi, C.C. (2014). Assessing the suitability of surface water for domestic purposes in Uburu; Southeast of Nigeria. IOSR Journal of Applied Chemistry, 7(2), pp. 45-49.

Beard, J.L. (2000). Iron biology in immune function, muscle metabolism and neuronal functioning. Journal of Nutrition, 131(28-2), pp. 5685-5695. 
Beldi, H., Gimbert, F., Maas, S., Scheifler, R. and Soltani, N. (2006). Seasonal variations of Cd, Cu, $\mathrm{Pb}$ and $\mathrm{Zn}$ in the edible Mollusc Donax trunculus (Mollusca, Bivalvia) from the gulf of Annaba, Algeria. African Journal of Agricultural Research, 1(4), pp. 85-90.

Benvenuti, M., Mascaro, I., Lattanzi, P., Parrini, P. and Tanelli, G. (1997). Minewaste dumps and heavy metal pollution in abandoned mining District of Boccheggiano Southern Tuscany, Italy. Environmental Geology, 30, pp. 238-243.

Bogaert, G. and Dumont, H.J. (1989). Community structure and coexistence of an artificial crater lake. Hydrobiologia, 186/187, pp. 167-179.

Bu, H., Wang, W., Song, X. and Zhang, Q. (2015). Characteristics and source apportionment of dissolved trace elements in the Jinshui River of the South Qinling Mts., China. Environmental Science and Pollution Research, 22(18), pp. 14248-14257.

Chia, M.A., Bako, S.P., Alonge, S.O. and Adamu, A.K. (2011). Green algal interactions with physicochemical parameters of some manmade ponds in Zaria, northern Nigeria. Revista Brasileira de Botanica, 34(3), pp. 285-295.

Cowell, B.C. (1960). A quantitative study of the winter plankton of Urschel's quarry. The Ohio Journal of Science, 60, pp. 183-191.

Dallman, P.R. (1986). Biochemical basis for the manifestations of iron deficiency. Anunal Reviews of Nutrition, 6, pp. 13-40.

Department of Petroleum Resources (DPR) (2002). Environmental guidelines and standards for the petroleum industry in Nigeria (EGASPIN).

Dissmeyer, G.E. (2000). Drinking water from Forests and Grasslands, South Research Station, USDA Forest Service, Ashville, NC, USA.

Edeani, C.F., (2015). Geochemistry of surface waters in Ishiagu, Ebonyi State, Nigeria. International Journal of Innovative Science, Engineering and Technology, 2(7), pp. 90-95.

Egbe, E.R., Nsonwu-Anyanwu, A.C., Offor, S.J., Usoro, C.A.O., Etukudo, M.H., et al. (2017). Element content of surface and underground water sources around a cement factory site in Calabar, Nigeria. Iranian Journal of Toxicology, 11(1), pp. 19-25.

Egboh, S.H.O. and Emeshili, E.M. (2007). Physicochemical characteristics of River Ethiope source in Umuaja, Delta State, Nigeria. Journal of Chemical Society of Nigeria, 32(2), pp. 72-76.

Eisler, R. (1985). Cadmium hazards to fish, wildlife, and invertebrates: A synoptic review. U.S. Fish and Wildlife Service Biological Report 85 (1.2), Contaminant Hazard Reviews Report No. 2. 46 pp.

Ekweozor, I.K.E., Ugbomeh, A.P. and Ogbuehi, K.A. (2017). Zn, Pb, Cr and Cd concentrations in fish, water and sediment from the Azuabie Creek, Port Harcourt. Journal of Applied Sciences and Environmental Management, 21(1), pp. 87-91.

Enuneku, A., Okoh, H. and Oronsaye, C. (2017). Assessment of water quality of Obueyinomo River, Ovia North east Local Government Area, Edo State, Southern Nigeria. Ethiopian Journal of Environmental Studies and Management, 10(4), pp. 505-519.

Feng, H., Jiang, H.Y., Gao, W.S., Weinstein, M.P., Zhang, Q.F., et al. (2011). Metal contamination in sediments of the western Bohai Bay and adjacent estuaries, China. Journal of Environmental Management, 92(4), pp. 1185-1197.

Federal Environmental Protection Agency, FEPA (1991) Guidelines and Standards for Environmental Pollution Control in Nigeria. National Environmental Standards-Parts 2 and 3, Government Press, Lagos, pp. 238.

FMEnv (2011) National Guidelines and standards for water quality in Nigeria. Publication Federal Ministry of Environment (FMENV), Lagos, Nigeria. pp: 114.

Galas, J. (2003). Limnological study on a lake formed in a limestone quarry (Kraków, Poland). I. Water chemistry. Polish Journal of Environmental Studies, 12, pp. 297-300. 
Garba, T., Ilelah, K.G., Gana, B.A., Lukman, S.S., Yusuf, A., et al. (2019). Analyses of the effects of abandoned mining pond on physio-chemical characteristics of water quality. American Journal of Engineering Research, 8(5), pp. 242-249.

Hotz, C., Lowe, N.M., Araya, M. and Brown, K.H. (2003). Assessment of the trace element status of individuals and populations: The example of zinc and copper. Journal of Nutrition, 133(5), pp. 15631560.

Hussain, N.I. and Abdullah, M.H. (2018). The assessment of water quality and metals concentration in surface water of Kenyir Lake. Malaysian Journal of Applied Sciences, 3(2), pp. 71-89.

Iganga, C.U., Aneke, N.A.G., Ejikeme, P.C.N. and Nwali, C.J. (2015). Comparative analysis and treatment of well water in Ebonyi State Nigeria. International Journal of Innovative Science, Engineering and Technology, 2(1), pp. 360-365.

Itumoh, E.J., Uraku, A.J., Omaka, O.N. and Nwabue, F.I. (2013). Trace metal toxicity in our environment: Case studies of influx of metals in soils, crops, waters and air in Ebonyi State. Global Journal of Bioscience and Technology, 2, pp. 33-36.

Jarup, L., Hellstrom, L., Alfven, T., Carlsson, M.D., Grubb, A., et al. (2000). Low level exposurecadmium and early kidney damage: the OSCAR Study. Occupational and Environmental Medicine, 57, pp. 668-672.

Keay, R.W.J. (1959). An outlines of Nigeria vegetation. 3rd ed. Government Printer, Lagos, Nigeria.

Kilonzo, W., Home, P., Sang, J. and Kakoi, B. (2019). The storage and water quality characteristics of Rungiri quarry reservoir in Kiambu, Kenya, as a potential source of urban water. Hydrology, 6(93), pp. 1-23.

Kusin, F.M, Jarvis, A.P. and Gandy, C.J. (2012). Hydraulic performance assessment of passive coal mine water treatment systems in the UK. Ecological Engineering, 49, pp. 233-243.

Kusin, F.M., Jarvis, A.P. and Gandy, C.J. (2014). Hydraulic performance and iron removal in wetlands and lagoons treating ferruginous coal mine waters. Wetlands, 34, pp. 555-564.

Kusin, F.M. and Aris, A. (2014). Anoxic limestone drain for treatment of highly acidic water. In: AZ Aris, TH Tengku Ismail, R Harun, AM Abdullah, MY Ishak (Editors); Proceedings of the International Conference on Environmental Forensics 2013, From Sources to Solution; Malaysia; Springer; 2014, pp. 369-373.

Lin, H.J., Sung, T.I., Chen, C.Y. and Guo, H.R. (2013). Arsenic levels in drinking water and mortality of liver cancer in Taiwan. Journal of Hazardous Material, 262, pp. 1132-1138.

Lind, O.T. (1979). A handbook of limnological methods. CV Mosby Co, St. Louis.

Macklin, M., Brewer, P., Balteanu, D., Coulthard, T., Driga, B., et al. (2003). The long term fate and environmental significance of contaminant metals released by the January and March 2000 mining tailings dam failure in Maramures County, upper Tisa basin, Romania. Applied Geochemistry, 18(2), pp. 241-257.

Madzin, Z., Shai-ina, M.F. and Kusin, F.M. (2015). Comparing heavy metal mobility in active and abandoned mining sites at Bestari Jaya in Selangor, Malaysia. Procedia Environmental Sciences, 30, pp. $232-237$.

Majuru, B., Mokoena, M.M., Jagals, P. and Hunter, P.R. (2011). Health impact of small-community water supply reliability. International Journal of Hygiene and Environmental Health, 214, pp. 162166.

Mathew, B.B., Jaishankar, M., Tseten, T., Anbalagan, N. and Beeregowda, K.N. (2014). Toxicity, mechanism and health effects of some heavy metals. Interdisciplinary Toxicology, 7(2), pp. 60-72.

Mbaneme, F.C.N., Okoli, G.C. and Obiano, E.C. (2018). Assessment of groundwater quality around abandoned quarry ponds near lower Benue Trough, Nigeria. Current Journal of Applied Science and Technology, 29(3), pp. 1-17. 
Mahulu, A., Mtoka, S. and Nongolo, K. (2015). Diversity of freshwater invertebrates in Wazo Hill quarry ponds. Entomology and Applied Science Letters, 2(2), pp. 20-25.

Navorro, M.C., Perez-Sirvent, C., Martinez-Sainchez, M.J., Vidal, J., Tovar, P.J. et al. (2007). Abandoned mine sites as a source of contamination by heavy metals: A case study in a semi-arid zone. Journal of Geochemical Exploration, 96, pp. 183-193.

Ngele, S. O., Itumoh, E. J., Onwa, N. C. and Alobu, F. (2014). Quality assessment of selected groundwater samples in Amike-Aba, Abakaliki Ebonyi State, Nigeria. Canadian Journal of Pure and Applied Science, 8(1), pp. 2801-2805.

Ngene, B.U., Tenebe, I.T., Emenike, P.C. and Airiofolo, R.I. (2015). Statistical evaluation of hydrometeorological data: a case study of Ishiagu in South-east zone Nigeria. ARPN Journal of Engineering and Applied Sciences, 10(18), pp. 8192-8199.

Njoku, C. and Ngene, P.N. (2015). Evaluation of water qualities of Ebonyi River for drinking purposes in Abakaliki southeastern Nigeria. Journal of Agriculture and Ecology Research International, 2(4), pp. 254-258.

Nnabo, P.N. (2015). Assessment of contamination of underground water sources in Enyigba $\mathrm{Pb}-\mathrm{Zn}$ district, south eastern Nigeria using metal enrichment and pollution indices. International Journal of Sciences, 4(9), pp. 46-57.

Nnabo, P.N. (2015). Assessment of heavy metal contamination of water sources from Enyigba Pb-Zn district, south eastern Nigeria. International Journal of Scientific and Technology Research, 4(9). pp. 187-197.

Nolan, K., (2003). Copper toxicity syndrome. Journal of Orthomolecular Psychiatry, 12(4), pp. 270282.

Nordberg, G.F., Nogawa, K., Nordberg, M., and Friberg, M. (2007). Cadmium, pp. 446-486 in Handbook on the Toxicology of Metals edited byG. F. Nordberg, B. A. Fowler, M. Nordberg, and L. T. Friberg, Academic Press/Elsevier, Amsterdam and Boston.

Nwachukwu, M.A., Ojeaga, K. and Gilbert, C. (2018). Critical issues of sustainability associated with quarry activities. Aspects in Mining and Mineral Resources, 1(2), pp. 58-65.

Ofoegbu, C.O. (1985). Interpretation of aeromagnetic profile across the Benue trough of Nigeria. Journal of African Earth Sciences, 3, pp. 293-296.

Ofomata, G.E.K. (2002). Relief, drainage and landforms in a survey of Igbo Nation. Africana Publishers Ltd., Onitsha, pp. 83-98.

Ogbonna, P.C., Emea, R. and Teixeira da Silva, J.A. (2011). Heavy metal concentration in soil and woody plants in a quarry. Toxicology and Environmental Chemistry, 93(5), pp. 895-903.

Ogbonna, P.C., Nzegbule, E.C. and Okorie, P.C. (2018a). Soil chemical characteristics in wet and dry season at Iva long wall underground mined site, Nigeria. Nigerian Journal of Environmental Sciences and Technology, 2(1), pp. 96-107.

Ogbonna, P.C., Ukpai, N. and Obasi, K.O. (2018b). Assessment of metal contamination in Ubeyi River and accumulation in fish and sediment. Journal of Applied Sciences Environmental Management, 22(8), pp. $1151-1157$.

Ogbonna, P.C., Nzegbule, E.C. and Okorie, P.E. (2018c). Seasonal variation in heavy metal accumulation in plants at coal mine sites and possible health risk. Nigerian Journal of Environmental Sciences and Technology, 2(2). pp. 196-207.

Ogbonna, P.C., Nzegbule, E.C. and Okorie, P.E. (2019). Investigation of floristic composition, species abundance and diversity of plant species in Akwuke and Iva mining sites, Enugu State, Nigeria. Nigerian Research Journal of Engineering and Environmental Sciences, 4(2), pp. 765-775.

Ogbonna, P.C., Demian, P.O., Ubuoh, E.A., Iwok, E.S. and Ukpai, N.P. (2020a). Potentially toxic element pollution levels in Clarias batracus (cat fish) and sediments of Onu Asu River in Arochukwu, Abia State, Nigeria. Nigerian Research Journal of Engineering and Environmental Sciences, 5(1), pp. 01-14. 
Ogbonna, P.C., Ukpai, N.P., Obasi, K.O. and Umezuruike, S.O. (2020b). Monitoring the distribution of potentially toxic elements in soil and accumulation in fodder and medicinal plant species at a quarry site in Ebonyi State, Nigeria. Nigerian Research Journal of Engineering and Environmental Sciences, (In Press).

Ogbonna, P.C., Ukpai, N.P. and Ubuoh, E.A. (2020c). Assessment of particulate matter $\left(\mathrm{PM}_{2.5}\right.$, $\mathrm{PM}_{10}$ ) in air, elemental composition of granite and weather parameters at a quarry site in Ebonyi State, Nigeria. Nigerian Journal of Environmental Sciences and Technology, 4(1), pp. 182-196.

Oguntuase, M.A., Adebawore, A.A., Osundare, O.S., Adamalekun, S.E., Araromi, A.A., et al. (2019). Comparative analysis of physicochemical properties of some selected water sources in Ekiti State, Nigeria. Advance Journal of Toxicology Current Research, 3(1), pp. 15-19.

Okere, U.J., Ugwu, T.O., Ufot, U.O. and Akamigbo, F.O.R. (2001). Management of wetland soils for sustainable agriculture and environment. Paper presented at the 27th annual conference of the soil science society of Nigeria, 5-9 $9^{\text {th }}$ November, 2001, University of Calabar, Cross River State, Nigeria, pp. 291-296.

Okovido, J.O., Owen-Egharevba, U. and Akhigbe, L.O. (2018). Rainwater harvesting system for water supply in a rural community in Edo State, Nigeria. Nigerian Journal of Environmental Sciences and Technology, 2(2), pp. 266-274.

Oladiji, A.T., Adeyemi, O. and Abiola, O.O. (2004). Toxicological evaluation of the surface water of Amilegbe River using rats. Biokemistri, 16, pp. 94-101.

Omaka, O.N., Nwabue, F.I., Itumoh, E.J., Oroke, E.C. and Igwe, D.O. (2014). Physicochemical parameter and nutrients in streams and rivers in Abakiliki, Ebonyi State, Nigeria. Global NEST Journal, 16(1), pp. 114-123.

Omotosho, A.O., Oyeleke, S.B., Daniyan, S.Y. and Egwim, E.C. (2019). Determination of the physicochemical properties of three Nigerian textile companies effluents in Kano, Kano State, Nigeria. Nigerian Research Journal of Engineering and Environmental Sciences, 4(2), pp. 740-745.

Osakwe, S.A. and Asuquo, U.I. (2017). Water quality assessment of River Niger at Asaba/ Onitsha axis, Nigeria. Nigerian Journal of Science and Environment, 15(1), pp. 163-175.

Pape, P., Ayrault, S. and Quantin, C. (2012). Trace element behavior and partition versus urbanization gradient in an urban river (Orge River, France). Journal of Hydrology, 99, pp. 472-473.

Rahmanian, N., Bt Ali, S.H, Homayoonfard, M., Ali, N.J., Rehan, M., et al. (2015). Analysis of Physiochemical Parameters to Evaluate the Drinking Water Quality in the State of Perak, Malaysia. Journal of Chemistry, 2015, pp. 1-10.

Rajappa, B., Manjappa, S. and Puttaiah, E. (2010). Monitoring of Heavy metal in groundwater of Hakinaka TaluK, India. Contemporary Engineering Sciences, 3(4), pp. 183-190.

Ruuskanen, A., Karell, K., Viitasaari, S., Järvinen, L., and Kekäläinen, P. (2013). Environmental properties of the water-filled Ojamo limestone quarry, southern Finland. Underwater Technology, 31(4), pp. 167-177.

Schwab, P., Zhu, D. and Banks, M.K. (2007). Heavy metal leaching from mine tailings as affected by organic amendments. Bioresource Technology, 98, pp. 2935-2941.

Shevenell, L, Connors, K.A. and Henry, C.D. (1999). Controls on pit lake water quality at sixteen open-pit mines in Nevada. Applied Geochemistry, 14, pp. 669-687.

Ślusarczyk, A. (2003). Limnological study of a lake formed in limestone quarry (Kraków, Poland). I. Zooplankton community. Polish Journal of Environmental Studies, 12, pp. 489-493.

Standards Organization of Nigeria, SON (2007). Nigerian standard for drinking water quality. Nigerian Industrial Standard (NIS 554). Standards Organization of Nigeria (SON), Abuja, Nigeria. pp. $14-17$. 
Sperotto, R.A., Ricachenevsky, F.K., Williams, L.E., Vasconcelos, M.W. and Menguer, P.K (2014). From soil to seed: micronutrient movement into and within the plant. Front Plant Sciences, 5, pp. 438-441.

Tekenah, W.E., Agi, P.I. and Babatunde, B.B. (2014). Analysis of surface water pollution from abattoirs and the interrelationship between physicochemical properties. (A case study of the New Calabar River). Journal of Environmental Science, Toxicology and Food Technology, 8(5), pp. 10-18.

Titilawo, Y., Nwakpa, F., Bankole, S., Nworie, O., Okoro, C., et al., (2020). Quality audit of drinking water sources in Ikwo rural setting of Ebonyi State, Southeastern Nigeria. Int J Energ Water Res, 36, https://doi.org/10.1007/s42108-020-00062-9.

Tirkey, A., Shrivastava, P. and Saxena, A. (2012). Bioaccumulation of heavy metals in different components of two Lakes ecosystem. Current World Environment, 7(2), pp. 293-297.

Ukiwe, L.N., Onyedika, G.O., Uche, V.I. and Iwu, C.I. (2012). Physicochemical water quality indicators of groundwater (boreholes) samples from five communities in Ishiagu, Ebonyi State, Nigeria. Terrestrial and Aquatic Environmental Toxicology, 6(1), pp. 55-60.

UN-Water, An increasing demand, facts and figures, UN-Water, coordinated by UNESCO in collaboration with UNECE and UNDESA, 2013, http://www.unwater.org/water-cooperation2013/en/.

United States Environmental Protection Agency (USEPA) (2018) Risk assessment, Regional Screening Levels (RSLs) for chemical contaminants at superfund sites-User's guide and summary generic tables.

Varol, M., Gokot, B. and Bekleyen, A. (2013). Dissolved heavy metals in the Tigris River (Turkey): spatial and temporal variations. Environmental Science and Pollution Research, 20, pp. 6096-6108.

Wang, S. and Mulligan, C.N. (2005). Occurrence of Arsenic contamination in Canada: Sources behavior and distribution. Science of the total Environment, 366, pp. 701-721.

World Health Organization, WHO (2003). International standard for drinking water. Vol. 12.

World Health Organization, WHO. (2007). Guidelines for drinking water quality. 3rd Ed. Health criteria and supporting information, Geneva.

WHO (2011). Guidelines for Drinking-Water Quality, 4th ed. World Health Organisation, Geneva, Switzerland.

Young, R.A. (2005). Toxicity profiles: Toxicity summary for cadmium. Risk Assessment Information System, RAIS, University of Tennesse. (rais.ornl.gov/tox/profiles/cadmium.shtml).

Zang, J.G.N and Edafetano, C.A. (2017). Metal pollution assessment of the abandoned mine ponds and ground water of parts of the Jos Plateau, North Central Nigeria. International Journal of Energy and Environmental Science, 2(3), pp. 63-72.

\section{Cite this article as:}

Ogbonna P.C., Ukpai N.P., Obasi, K.O. and Umezuruike S.O., 2020. Appraising the physico-chemical characteristics and heavy metals in pond water at quarry site in Ngwogwo, Ebonyi State, Nigeria. Nigerian Journal of Environmental Sciences and Technology, 4(2), pp. 237-252. https://doi.org/10.36263/nijest.2020.02.0203 